\title{
The project must count: Fostering positive attitudes toward the conduct of research
}

\author{
DAVID R. GLASGOW, CYRIL J. SADOWSKI, and STEPHEN F. DAVIS \\ Austin Peay State University, Clarksville, Tennessee 37040
}

\begin{abstract}
Recent years have witnessed increasing concern on the part of the psychological community regarding the effects of research practices on subjects. Although considerable research has been directed at the impact of debriefing on eliminating harmful effects, little attention has been given to factors that influence subjects' perceptions of the conduct of research. Subjects ( $n=406$ ) in the present study read descriptions of six actual experiments which involved deception and stress. Subject status (volunteer vs. nonvolunteer) and scientific value of the research (widespread vs. limited use of results) dimensions were manipulated. Subjects rated each described experiment as ethical or nonethical. Analyses of these ratings indicated that potential subjects had a significant concern over the scientific value of the research, especially in cases where stress or discomfort were involved. Experimenters interested in fostering positive attitudes toward the conduct of research would be wise to take this factor into consideration in dealing with subjects.
\end{abstract}

Since the publication of Ethical Principles in the Conduct of Research with Human Participants (APA, 1973), psychologists have shown an increased sensitivity regarding the effects of research practices on subjects. The bulk of the research in this area has focused on the ability of debriefing techniques to remove misconceptions that participants could have about their behavior and correct any undesirable consequences that could result from research procedures (cf. Holmes; 1976a, 1976b). This emphasis on the safeguarding function of debriefing is not surprising, since the guidelines were established primarily for the protection of research participants and stress this aspect of researchers' responsibility. However, the guidelines also identify another facet of professional responsibility-shaping participants' attitudes toward the conduct of research itself.

The importance of this "public relations" role was recognized early in the debate over research practices. Psychological research has been described rather unfavorably in the popular press (Rubin, 1970), and the blame for this, in part, rests with researchers themselves. Steiner (1972) noted that the major abuse of human subjects was not that they were sometimes deceived or put through minor stresses, but that their time and energy were often wasted in many useless research endeavors. He contended: "If psychological research has a bad name, it is probably not because we injure a lot of subjects but because we involve subjects in trivial, ill-conceived, or clumsily executed studies" (p. 768).

This charge takes on added significance when one

Requests for reprints should be sent to Cyril J. Sadowski, Department of Psychology, Austin Peay State University, Clarksville, Tennessee 37040. considers that psychologists are regarded somewhat reverentially due to their area of study (Schultz, 1969). That such an attitude is brought to the laboratory seems apparent from the results of a recent survey which indicated that naive subjects view deceptive research practices more favorably than psychologists themselves (Sullivan \& Deiker, 1973). Indeed, Orne (1962) has even demonstrated that subjects would willingly accept the tedium of circling numbers for excessively long periods of time under the pretext of advancing the science.

The literature suggests that subjects' positive regard toward the conduct of research can be effectively maintained even when the participants have been deceived or undergone stressful experiences. Perhaps the classic example is Milgram's follow-up on his obedience study (Milgram, 1964). After the purpose of the experiment was explained to the subjects, only $1.3 \%$ reported negative feelings about their participation. Results of various role-play simulations and empirical tests of debriefing strategies following participation in actual experiments indicate that negative impressions may be eliminated and the perceived value of the project enhanced when the subjects' participation in the research is made meaningful to them (Bersceid, Baron, Dermer, \& Libman, 1973; Ring, Wallston, \& Corey, 1970; Ross, Lepper, \& Hubbard, 1975; Straits, Wuebben, \& Majka, 1972).

In the present study college students read descriptions of six actual experiments in which subjects were deceived and, in some cases, put through extensive stress. The meaningfulness of the subjects' participation was operationalized by indicating the extent to which the results were incorporated as worthwhile data for the scientific community. Also, the subjects in the experi- 
ments were described as being either volunteers or nonvolunteers. This dimension was included because volunteers have been shown to have a more positive attitude toward research than nonvolunteers (Gustav, 1962; Rosenthal, 1965), and the impact of the scientific value of the endeavor might depend on the status of the subjects.

\section{METHOD}

Subjects

The subjects were 416 undergraduates enrolled in introductory psychology courses. In the fall of 1973, 225 students participated in the study at David Lipscomb College, and 191 participated at Austin Peay State University in the fall of 1976. Since 10 Lipscomb students did not complete the questionnaire, the final sample size was 406 .

\section{Materials and Procedure}

A booklet with a cover sheet of instructions and descriptions of six deception experiments was presented to the subjects. The cover sheet explained that psychologists sometimes employ deception so that the observed behavior might reflect what would occur in a real-life situation. Since the general public is more familiar with medical research, an allusion was made to the use of "sugar pill" groups as an analogy. It was stated that the true nature of the study was usually explained to the subjects following the experiment.

The cover sheet then added that recent years had seen increased concern "in regard to whether some psychological experiments in which subjects are deceived are actually ethical." It also said that "psychologists have largely discussed the matter, both pro and con," and concluded that one ingredient that seemed to be lacking was "judgments of those who might well, given another setting, have been subjects in the various experiments." The students were informed that following would be "several experiments, some real and some that might well have been real," and that after reading and considering each they should rate it as ethical or nonethical. A final note enjoined, "Remember, most of the actual experiments were performed on persons much like you."

All questionnaires contained descriptions of six experiments in the same order as follows:

(1) Asch's (1956) study on conformity in judging line lengths, (2) A study by Berkun, Bialek, Kern, and Yagi (1962) in which soldiers were deceived to believe they were in highly stressful situations, (3) Festinger and Carlsmith's (1959) forcedcompliance cognitive dissonance study, (4) Milgram's (1963) behavioral study of obedience, (5) Rosenthal and Jacobson's (1968) study of the self-fulfilling prophecy with school children, and (6) Schacter's (1959) study on affiliation under the stress of impending electric shocks.

In describing each study, emotionally biasing words and possibly unfamiliar terms were avoided. The descriptions of each study were identical except for a phrase at the beginning noting that the subjects were either volunteers or nonvolunteers and a note at the end describing the results as having received wide or limited usage. By way of illustration, the description of the Berkun et al. (1962) study is presented in all phases:

"A team of army psychologists used servicemen who volunteered (were required) to take part in an experiment in tactical exercises. The study actually sought to determine what effects stress might have in preventing a soldier from carrying out necessary activities. Soldiers were taken individually to an isolated shack. They were shown that the only link to others outside the area was a radio. In reality, however, the psychologists had hidden an intercom through which the subject's well-being could be monitored. Around 60 minutes after the experiment began, a helicopter flew over the area to visually observe if the subject seemed all right. The experiment lasted 75 minutes.

"Shortly after others had left, the subject was led to believe one of three things: (1) he was in the path of a forest fire, (2) he was in an area of high atomic radiation, or (3) he had unintentionally blown up one of his comrades. Each situation required the subject to contact headquarters by radio. His radio, however, would receive but would not transmit. In order to repair it, he had to follow a set of instructions in sequence.

"The psychologists found that stress from the supposed danger did impair the subject's performance in repairing the radio. Subjects were afterward informed of the actual experimental happenings and the reasons for them. No apparent use has been made of the study, however, other than its being printed in a small army periodical. (Results of this study were published not only in army literature, but in university, government, and industry circles as well. Knowledge gained from the research has been highly beneficial in programs designed to help servicemen and employees learn to cope with and minimize stress.)"

Four forms of the questionnaire were devised. For each described experiment, the scientific value and subject status dimensions were varied orthogonally across the forms of the questionnaire. The combinations of specific conditions for the studies presented in each form were randomly determined. The questionnaires were distributed in alternating order during a regular class period in all cases. The few questions that occurred.were answered by addressing attention to the cover sheet and emphasizing applicable sections. No time limit was imposed for comple-

Table 1

Frequency of Ethical Judgments by Use of Results and Status of Subjects

\begin{tabular}{|c|c|c|c|c|c|c|c|c|c|c|c|c|c|c|c|}
\hline \multirow[b]{2}{*}{ Judgments } & \multicolumn{2}{|c|}{ Widespread Use } & \multicolumn{2}{|c|}{ Limited Use } & \multirow[b]{2}{*}{ Total } & \multicolumn{2}{|c|}{ Widespread Use } & \multicolumn{2}{|c|}{ Limited Use } & \multirow[b]{2}{*}{ Total } & \multicolumn{2}{|c|}{ Widespread Use } & \multicolumn{2}{|c|}{ Limited Use } & \multirow[b]{2}{*}{ Total } \\
\hline & NV Ss & V Ss & NV Ss & V Ss & & NV Ss & V Ss & NV Ss & V Ss & & NV Ss & V Ss & NV Ss & V Ss & \\
\hline & \multicolumn{5}{|c|}{$\begin{array}{l}\text { Asch (1956) } \\
\text { Conformity in Line Judgment Task }\end{array}$} & \multicolumn{5}{|c|}{$\begin{array}{l}\text { Rosenthal \& Jacobson (1968) } \\
\text { Self-Fulfilling Prophecy }\end{array}$} & \multicolumn{5}{|c|}{$\begin{array}{c}\text { Schacter (1959) } \\
\text { Affiliation Under Stress }\end{array}$} \\
\hline $\begin{array}{l}\text { Ethical } \\
\text { Nonethical } \\
\text { Total }\end{array}$ & $\begin{array}{r}84 \\
17 \\
101\end{array}$ & $\begin{array}{r}103 \\
6 \\
109\end{array}$ & $\begin{array}{l}85 \\
14 \\
99\end{array}$ & $\begin{array}{l}84 \\
13 \\
97\end{array}$ & $\begin{array}{r}356 \\
50 \\
406\end{array}$ & $\begin{array}{l}82 \\
15 \\
97\end{array}$ & $\begin{array}{r}88 \\
21 \\
109\end{array}$ & $\begin{array}{l}76 \\
23 \\
99\end{array}$ & $\begin{array}{r}72 \\
29 \\
101\end{array}$ & $\begin{array}{r}318 \\
88 \\
406\end{array}$ & $\begin{array}{r}82 \\
19 \\
101\end{array}$ & $\begin{array}{l}76 \\
23 \\
99\end{array}$ & $\begin{array}{r}67 \\
42 \\
109\end{array}$ & $\begin{array}{l}53 \\
44 \\
97\end{array}$ & $\begin{array}{l}278 \\
128 \\
406\end{array}$ \\
\hline & \multicolumn{5}{|c|}{$\begin{array}{c}\text { Festinger \& Carlsmith (1959) } \\
\text { Forced Compliance }\end{array}$} & \multicolumn{5}{|c|}{$\begin{array}{l}\text { Berkun, Bialek, Kern, \& Yagi (1962) } \\
\text { Soldiers Under Stress }\end{array}$} & \multicolumn{5}{|c|}{$\begin{array}{c}\text { Milgram (1963) } \\
\text { Obedience to Authority }\end{array}$} \\
\hline $\begin{array}{l}\text { Ethical } \\
\text { Nonethical } \\
\text { Total }\end{array}$ & $\begin{array}{r}82 \\
27 \\
109\end{array}$ & $\begin{array}{l}78 \\
19 \\
97\end{array}$ & $\begin{array}{r}39 \\
62 \\
101\end{array}$ & $\begin{array}{l}44 \\
55 \\
99\end{array}$ & $\begin{array}{l}243 \\
163 \\
406\end{array}$ & $\begin{array}{l}62 \\
37 \\
99\end{array}$ & $\begin{array}{r}54 \\
47 \\
101\end{array}$ & $\begin{array}{l}29 \\
68 \\
97\end{array}$ & $\begin{array}{r}35 \\
74 \\
109\end{array}$ & $\begin{array}{l}180 \\
226 \\
406\end{array}$ & $\begin{array}{l}48 \\
49 \\
97\end{array}$ & $\begin{array}{l}54 \\
45 \\
99\end{array}$ & $\begin{array}{r}35 \\
74 \\
109\end{array}$ & $\begin{array}{r}34 \\
67 \\
101\end{array}$ & $\begin{array}{l}171 \\
235 \\
406\end{array}$ \\
\hline
\end{tabular}

Note $-N V S s=$ nonvolunteer subjects, $V S s=$ volunteer subjects 
Table 2

Partitioned Chi Squares: The Effects of the Independent Variables on Ethical Judgments

\begin{tabular}{|c|c|c|c|c|c|c|}
\hline Source & $\mathrm{df}$ & Chi Square & $\mathrm{df}$ & Chi Square & df & Chi Square \\
\hline & \multicolumn{2}{|c|}{$\begin{array}{l}\text { Asch (1956) } \\
\text { Conformity in Line } \\
\text { Judgment Task }\end{array}$} & \multicolumn{2}{|c|}{ Rosenthal \& Jacobson (1968) } & \multicolumn{2}{|c|}{ Schacter (1959) } \\
\hline $\begin{array}{l}\text { Total } \\
\text { Use of Results by Ethical Judgments } \\
\text { Status of Subjects by Ethical Judgments } \\
\text { Use by Status by Ethical Judgments }\end{array}$ & $\begin{array}{l}3 \\
1 \\
1 \\
1\end{array}$ & $\begin{array}{l}6.99 \\
.72 \\
3.70^{*} \\
2.57\end{array}$ & $\begin{array}{l}3 \\
1 \\
1 \\
1\end{array}$ & $\begin{array}{l}5.66 \\
4.35^{* *} \\
1.16 \\
.15\end{array}$ & $\begin{array}{l}3 \\
1 \\
1 \\
1\end{array}$ & $\begin{array}{l}21.79 \\
20.23 * * * \\
1.24 \\
.32\end{array}$ \\
\hline & \multicolumn{2}{|c|}{$\begin{array}{c}\text { Festinger \& Carlsmith (1959 } \\
\text { Forced Compliance }\end{array}$} & \multicolumn{2}{|c|}{$\begin{array}{l}\text { Berkun et al. (1962) } \\
\text { Soldiers Under Stress }\end{array}$} & \multicolumn{2}{|c|}{$\begin{array}{l}\text { Milgram (1963) } \\
\text { Obedience to Authorit }\end{array}$} \\
\hline $\begin{array}{l}\text { Total } \\
\text { Use of Results by Ethical Judgments } \\
\text { Status of Subjects by Ethical Judgments } \\
\text { Use by Status by Ethical Judgments }\end{array}$ & $\begin{array}{l}3 \\
1 \\
1 \\
1\end{array}$ & $\begin{array}{l}56.53 \\
55.23 * * * \\
.91 \\
.39\end{array}$ & $\begin{array}{l}3 \\
1 \\
1 \\
1\end{array}$ & $\begin{array}{l}31.63 \\
29.82 * * * \\
.66 \\
1.15\end{array}$ & $\begin{array}{l}3 \\
1 \\
1 \\
1\end{array}$ & $\begin{array}{l}15.87 \\
15.30^{* *} \\
.57 \\
.00\end{array}$ \\
\hline
\end{tabular}

tion. The participants were not identified in any way on the questionnaires, and they were debriefed regarding the design and purpose of the study.

\section{RESULTS}

The data from the two samples were first transformed via the arc-sine transformation and analyzed by means of an ANOVA technique developed by Abelson and his colleagues (Langer \& Abelson, 1972; Zanna, Lepper, \& Abelson, 1973). Since there were no significant interactions between the samples and the independent variables, the data were combined. The frequencies are presented in Table 1.

Table 1 presents the stimulus studies (left to right) in descending order based on the judgments of how ethical each was considered to be. The ordering of the studies suggests that subjects consider undergoing psychological stress substantially more unethical than merely being deceived. While this is consistent with the findings of Sullivan and Deiker (1973) that psychologists are more concerned over ethical issues than are lay people, a more realistic interpretation is that subjects probably consider their own discomfort to be more important than an investigator's honesty.

The results of the partitioned chi-square analyses for each study presented in Table 2 indicate that the scientific value of the study had a significant effect on the subjects' ethical judgments. In all but the most innocuous case, making the project seem like a worthwhile endeavor enhanced the subjects' views regarding the conduct of research. On the other hand, status of the subjects had a marginal effect only within the Asch (1956) study $\left[\chi^{2}(1)=3.70, p<.06\right]$. This reflects the finding that the increased scientific value of the project enhanced the ratings when the subjects were described as volunteers $\left[\chi^{2}(1)=3.82, p<.06\right]$ but not when they were reported to be nonvolunteers $\left[\chi^{2}(1)=.27\right]$.

\section{DISCUSSION}

The present study suggests that, in instances where deception is employed, positive attitudes toward the conduct of research can be fostered when subjects are led to feel that they have contributed to a worthwhile endeavor. From the ratings of the studies, it also appears that such procedures would be particularly beneficial in cases where the subjects experience psychological stress, as in the Berkun et al. (1962) and Milgram (1963) studies.

Considering that attitudes formed in previous experiments influence performance in and evaluation of later experiments (Holmes, 1967), these findings imply that debriefing sessions should be made highly informative to participants. Obviously, since it cannot be known in advance whether a study will be published, let alone receive widespread application, subjects cannot be given the type of information used in the present study to indicate scientific value. However, a recent study by Ross et al. (1975) provides a technique that seems to meet this end. These authors found that describing research procedures in detail plus explaining the psychological processes involved and their implication (process debriefing) eliminated the negative aftereffects of false feedback, while merely explaining about the use and need for deception (outcome debriefing) was not particularly effective. Such process debriefing allows subjects to see their role as being scientifically valuable and to view themselves as more than human guinea pigs. Although adopting this type of debriefing would increase the time per subject in an experiment, it does appear to be cost effective in the long run.

As a final word, researchers' views of ethical standards as being for the protection of the subject while ignoring the public relations aspects of such procedures is indeed noteworthy. Perhaps this reflects our genuine, if somewhat abstract, interest in people, or perhaps we have just tried to avoid appearing selfserving in public. In either case, others recognize that adherence to ethical standards benefits long-term self-interest (Baier, 1977). The present study suggests that adopting this perspective could also prove advantageous for psychologists.

\section{REFERENCES}

American Psychological Association. Ethical principles in the conduct of research with human participants. Washington. D.C: Author. 1973. 
Asch. S. E. Studies of independence and conformity: I. A minority of one against a unanimous majority. Psychological Monographs. 1956. 70(9. Whole No. 416).

BAIER, K. Self-interest and morality. In K. J. Struhl \& P. R. Struhl (Eds.). Ethics in perspective. New York: Random House, 1975.

Berkun, M.. Bialek, H., Kern, R., \& Yagi, K. Experimental studies of psychological stress in man. Psychological Monographs, 1962, 76(15, Whole No. 534).

Bersceid. E., Baron, R. S., Dermer, M., \& Libman, M. Anticipating informed consent: An experimental approach. American Psychologist, 1973, 28. 913-925.

Festinger. L.. \& Carlsmith, J. M. Cognitive consequences of forced compliance. Journal of Abnormal and Social Psychology, 1959. 58. 203-210.

Gustav, A. Students attitudes toward compulsory participation in experiments. Journal of Psychology, 1962, 53, 119-125.

Holmes. D. S. Amount of experience as a determinant of performance in later experiments. Journal of Personality and Social Psychology, 1967. 7. 403-407.

Holmes. D. S. Debriefing after psychological experiments: I. Effectiveness of postdeception dehoaxing. American Psychologist, 1976, 31, 858-867. (a)

Holmes. D. S. Debriefing after psychological experiments: II. Effectiveness of postdeception desensitization. American Psychologist, 1976, 31, 868-875. (b)

LANGer. E. J..\& Abelson, R. P. The semantics of asking a favor: How to succeed in getting help without really dying. Journal of Personality and Social Psychology, 1972, 24, 26-32.

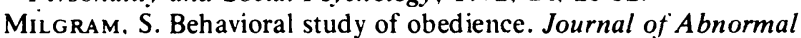
and Social Psychology. 1963, 67, 371-378.

Milgram. S. Issues in the study of obedience: A reply to Baumrind. American Psychologist, 1964, 19, 848-852.

ORNE. M. T. On the social psychology of the psychological experiment: With particular reference to demand characteristics and their implications. American Psychologist, 1962, 17. 776-783.
Ring, K., W Allston, K., \& Corey, M. Mode of debriefing as a factor affecting subjective reaction to a Milgram-type obedience experiment: An ethical inquiry. Representative Research in Social Psychology, 1970, 1. 67-88.

Rosenthal, R. The volunteer subject. Human Relations, 1965. 18. 398-406.

Rosenthal, R., \& Jacobson, L. Pygmalion in the classroom. New York: Holt. Rinehart, \& Winston, 1968.

Ross, L.. Lepper, M. R. . \& Hubbard, M. Perseverance in selfperception and social perception: Biased attribution processes in the debriefing paradigm. Journal of Personality and Social Psychology, 1975, 32, 880-892.

Rubin, Z. Jokers wild in the lab. Psychology Today, December 1970, 18, 20, 22-24. 79.

SChacter. S. The psychology of aftiliation. Stanford, Calif: Stanford University Press. 1959.

Schultz. D. P. The human subject in psychological research. Psychological Bulletin, 1969, 72, 214-228.

STEINER. I. D. The evils of research: Or what my mother didn't tell me about the sins of academia. American Psychologist. 1972. 27, 766-768.

Straits, B. C., Wuebren. P. L., \& Majka, T. J. Intluences on subjects' perceptions of experimental research. Sociometry. 1972, 35, 499-518.

Sullivan, D. S., \& Deiker, T. E. Subject-experimenter perceptions of ethical issues in human research. American Psychologist, 1973, 28, 587-591.

Zanna, M. P., Lepper, M. R., \& Abelson, R. P. Attentional mechanisms in children's devaluation of a forbidden toy. Journal of Personality and Sociul Psychology, 1973, 28. 355-359.

(Received for publication August 12. 1977.) 